る。

（1）噴流拡散係数は低圧と高圧とに区別されて表わ されることがわかつた。

（2）遷移長さは, 低圧領域では圧力が増すにつれて, 減少するが，高圧領域では圧力に無関係に一定となるこ とがわかつた。

（3）噴流半径方向の圧力分布は低圧噴流と高圧噴流 飞, 同一の乱流理論式が適応されることがわかつた。

$$
\text { 記号 }
$$

$P_{0}, P_{m}, P=$ ンズルロ, 噴流中心軸上および噴流断 面上の任意の点の圧力 $\left[\mathrm{kg} / \mathrm{cm}^{2}\right]$

$l, l_{T}=$ 二噴流軸上におけるノズルからの距離お よび遷移長さ $[\mathrm{m}]$

$D_{0}, D_{l}, R_{l}, R=$ ノズル口径, 距離 $l$ における噴流径お
よび半径と任意半径 [m]

$$
\begin{aligned}
& J_{e} \quad=\text { ジェット数 } \frac{2 \gamma H_{0} D_{0}}{\sigma}\left(\frac{\gamma_{a}}{\gamma}\right)^{0.55} \\
& \gamma, \gamma_{a}=\text { 水招よび空気の比重量 }\left[\mathrm{kg} / \mathrm{m}^{3}\right] \\
& \sigma \quad \text { 二水の表面張力 }[\mathrm{kg} / \mathrm{m}] \\
& H_{0} \quad=\text { フズル出口压力水頭 }[\mathrm{m}] \\
& L, B=\text { =ノズル長さ拈よびノズル入口幅 }[\mathrm{m}] \\
& \theta_{0} \quad=\text { フズル出口傾斜角 }
\end{aligned}
$$$$
\text { 参考 文 献 }
$$

1）吉沢・川島・柳井田：水力採炭江関与る基碟的研究一隫流特性江 ついて一（第 1 報）東北埕山，第 11 巻，第 2 号，昭和 39 年 9 月

2）吉沢・川島・柳井田：水力採孷阙する基碟的研究一ノズル性能 の判定について一(第 2 報)東北鉱山，第 12 巻, 第 1 号, 昭和 40 年 6 月

3）吉沢・川島・楖井田：噴流特性によるノズル性能の判定について 日本釷業会誌, 第 81 巻, 第 930 号, 昭和 40 年 10 月

\title{
1209 高周波による輸送管中の石炭濃度測定法について
}

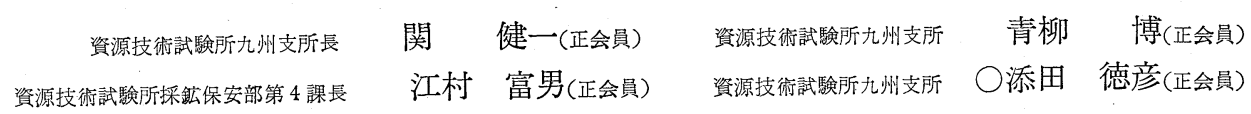

\section{1. まえがき}

水力輸送等の輸送管中の固形物濃度の連続測定につい てはすでに二，三の方法が発表されている。しかしなが ら, 濃度変化に伴らパイプ中の摩擦損失より求める方法 は流速変化による誤差が著るしく, 液の見掛け比重変化 に伴うパイプの撓みから求める方法は石炭の比重変化に よる誤差を生じ, しかも, 高品位の低比重炭の場合は感度 が低下する。また，放射能による測定は特殊の技術と資 格が必要で，しかも，装置が高価であるららみがある。

一方，化学分析の新分野として開発された高周波分析 法は今や素人の智識領域となつているラジオ周波数を利

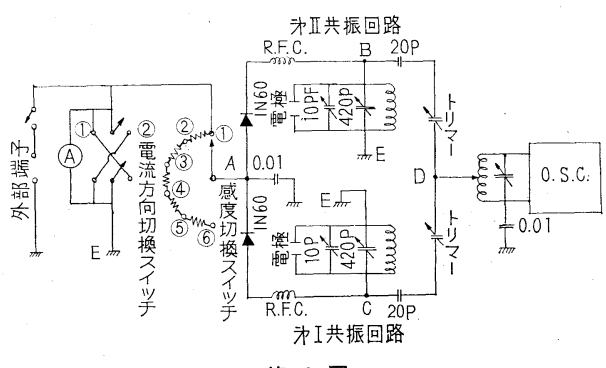

第 1 図

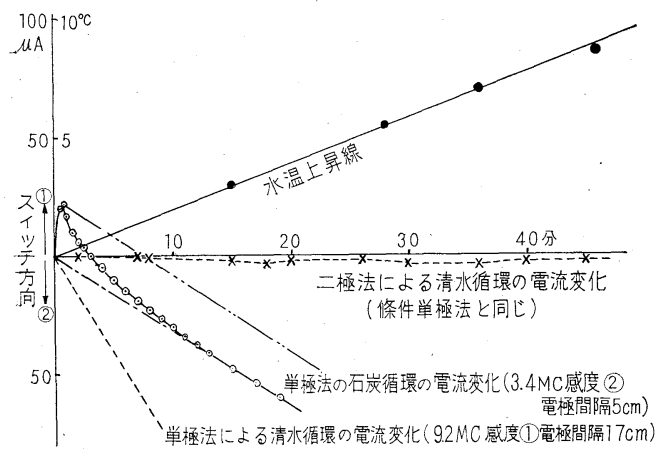

$208\langle 28\rangle$
用するもので, 試作や取り扱いが容易で既成品むまた廉 価である。しかも高周波を利用しているためその測定信 号をそのまま送信記録することができ，また，それによ る自動制御が容易に行なわれる利点がある。

以上のことから輸送管中の石炭濃度の測定に高周波法 を応用してみた。

\section{2. 実験装置}

測定器は受信型で等価回路は第 1 図のと括りである。
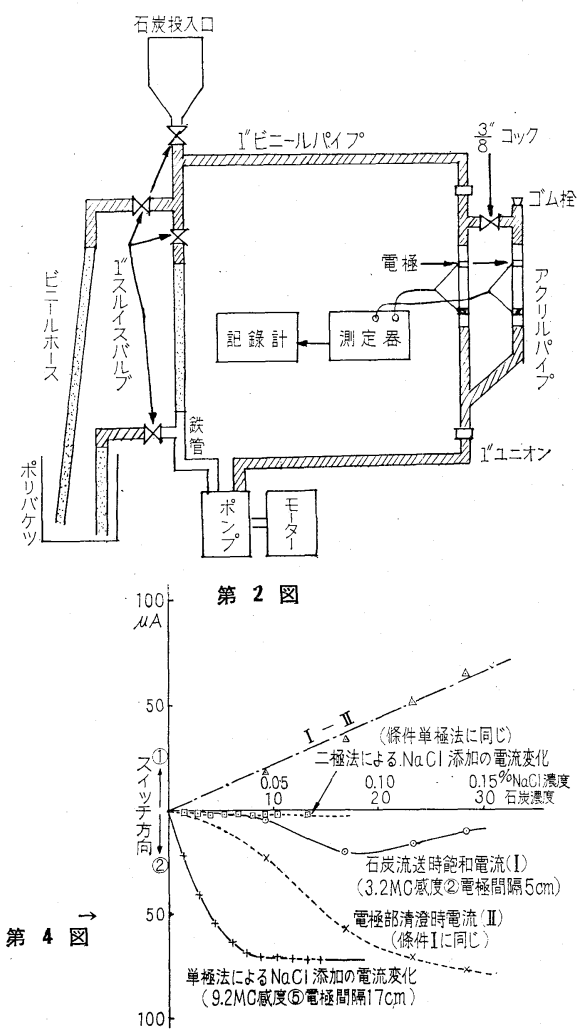

日本鉱業会誌 
(1)

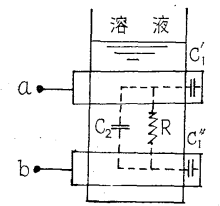

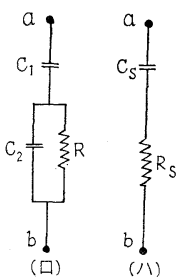

第 5 図

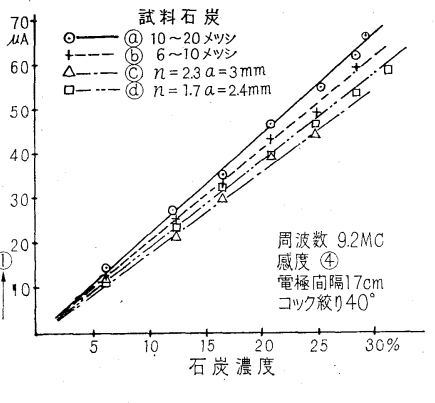

第 6 図

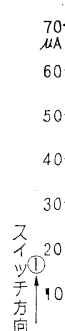

主用周波数と電極は $9.2 \mathrm{M} \mathrm{C}$ と間

隔 $17 \mathrm{~cm}$ のコンデンサ型である。 感度(1)で $100 \mu \mathrm{A}$ の場合 (2)・(3)・(4)・ (5).6) では $58 \cdot 36 \cdot 19 \cdot 9.5 \cdot 3 \mu \mathrm{A}$ で

めつた。第 1 図の DC・CE・DB・BEの各インピーダンス を $Z_{1} \cdot Z_{2} \cdot Z_{3} \cdot Z_{4}, \mathrm{~A}$ 点の電位を $V$ とし, $\mathrm{DE}$ E間に電圧 $V_{0}$ が掛つたとすると，

$$
V=V_{0}\left(Z_{2} Z_{3}-Z_{4} Z_{1}\right) /\left(Z_{1}+Z_{2}\right)\left(Z_{3}+Z_{4}\right)
$$

ここで, $Z_{1}=Z_{3}, Z_{1} \gg Z_{2}, Z_{3} \gg Z_{4}$ とすれば，

$$
V=V_{0}\left(Z_{2}-Z_{4}\right) / Z_{1}
$$

ゆえに,電流切換方向(1)の時は $Z_{2}>Z_{4}$, (2)の時は $Z_{2}<Z_{4}$ であることを示す。

輸送管回路は第 2 図のと打りで, 多くは水道用 $1^{\prime \prime}$ ビ ニールパイプを，測定部は厚さ $2.6 \mathrm{~mm}$, 内径 $24.3 \mathrm{~mm} の$ 透明アクリルパイプを用いた。バイパスのコックの絞り は開放の時を $0^{\circ}$ とし, 以下 $10^{\circ}, 20^{\circ}, 30^{\circ}, 40^{\circ}$ に取つた。

\section{3. 結果および考察}

\section{$3 \cdot 1$ 単極法による測定}

第 I 共振回路にのみ電極を付けて $10 \%$ 石炭を流すと 第 3 図○実線の電流変化となり，12分以後の直線を延長 すると一点鎖線となつて原点に交わる。水道水のみの循 環では点線となり，この時水温も直線的に上昇するので 12分以後の電流変化はポンプ運転や摩擦での水温変化に よる。水温変化のみであれば実線のピークから二点鎖線 の経過となるべきであるので12分までの電流変化は石炭 より溶出する電解質にも原因する。

清水に $\mathrm{NaCl}$ を加えると第 4 図○実線となる。この場 合の電極のインピーダンス $Z_{p}$ を考学ると，その等価回 路は第 5 図（イ）で，これはさらに（ハ）にま之められ $C_{s}$ と $R_{s}$ は $\omega$ が周波数の時それぞれ次式で示され，

$$
R_{s}=R /\left(\omega^{2} C_{2}^{2} R^{2}+1\right)
$$

$$
C_{s}=C_{1}\left(\omega^{2} C_{2}^{2} R^{2}+1\right) /\left\{\omega^{2} C_{2}{ }^{2}\left(C_{1}+C_{2}\right) R^{2}+1\right\}
$$

$R \rightarrow$ 小の時は $R_{s} \rightarrow R, C_{s} \rightarrow C_{1}$ となつて $C_{2}$ の影響はな くなり, 試料の誘電率変化は利用できなくなつて, $Z_{p}$ は

$$
Z_{p} \fallingdotseq R+1 / j \omega C_{1}
$$

となり， $Z_{p}$ の変化でメーターに現われる電流変化はほ そんぞRの変化によつて生じる。これから第 3 図の $\mathrm{NaCl}$
添加は $R \rightarrow$ 小で $Z_{2} \rightarrow$ 小となることが確めら れ，水温上昇でも $R \rightarrow$ 小となり，石炎添加 はR $R \rightarrow$ 大なる。

水温上昇を防ぐため間久運転すると石炭 流送時と電極部清澄時の電流は 8〜5 回で 一定となる。これを図示すると第 4 図○実 線と×点線となるが，両者の差を取ると今 一点鎖線となつて石炭濃度に比例した直線 が得られる。これは電解質溶出の影響を補 正したことになつているので，水温と電解 質の影響を補正すれば高周波による石炭濃 度測定が可能であることが解る。

\section{$3 \cdot 2$ 二極法による測定}

電解質などの影響を除くためには複々同 調回路などが考案されているが，電気抵抗が著るしく低 い時は $C_{2} \rightarrow 0$ となり，前記の方法でも十分でないので， 第 2 図のように絞りコック付きのバイパスを設けて同漛 な電極を第II共振回路にも取り付けて二極法とし，両方 の回路に同様に水温などの影響を与えて互いに打消すよ うにした。第 3 図の $\times$ 点線と第 4 図・点線は二極法での 水温と電解質の影響を示し，これらが充分補正されてい ることが解る。

パイパスにも石炭が流入するための誤差は絞りを適当 にすれば微粉のみの誤差となる。絞り $40^{\circ}$ の時バイパス の流速は $2.5 \mathrm{~cm} / \mathrm{sec} て ゙$ 岁つたので, 石炭の比重 1.5 , 水の 粘性1.0019センチポアズとすると，その流速での最大粒 径は0.096mmとなり，Rosin-Rammler 分布法則の分布 定数 $n$ を 1 とし,粒度特性数 $a か ゙ 10.5 \cdot 1 \mathrm{~mm}$ の場合の 0.0 $96 \mathrm{~mm}$ 以下の重量は0.97,2.13,9.15\%となる。これから $n=1, a=1 \mathrm{~mm}$ のようなスラリーではかなりの愦差を生 じるが，坑内の水力輸送の場合など微粉の少ない時はそ の誤差は無視できる。第 6 図は粒度の異なつた試料によ る結果で，試料(2)(ゆは微粉がないのでほぼ一致するは ずであるから両者の相違はこの装置の再現性を示し，こ の程度の粒度では濃度 $30 \%$ 付近で約士 $2 \%$ 誤差を生じ る。また微粉の量は(b>@>〕であるから微粉の多いる のほど低い濃度を示し，この測定法は粒度の小さい場合 は粒度分布にある程度影響されることを示している。

\section{4.むす び}

高周波に利用した二極法の石炭濃度測定法は本実験に 用いた粒度では必ずしも良好な結果を示さないが，これ は装置が小型で粗粒炭試料を使用できなかつたことによ ると考えられ，微粉量が無視できる坑内の水力輸送など では充分な精度が期待される。しかし，また一方，本測 定法が微粉の場合，試料の粒度分布にかなり影響される ことは，逆に本測定法および装置を改善すれば輸送管中 の粒度分布測定の可能性を暗示していると思われる。 